\title{
Cytotoxic Effect of Soy Bean Saponin against Colon Cancer
}

\author{
Mai M. El-Keiy*, Aliaa M. Radwan, Tarek M. Mohamed \\ Biochemistry Division, Chemistry Department, Faculty of Science, Tanta University, Tanta, Gharbia, Egypt \\ Email: *Mai.Ibrahim@science.tanta.edu.eg
}

How to cite this paper: El-Keiy, M.M., Radwan, A.M. and Mohamed, T.M. (2019) Cytotoxic Effect of Soy Bean Saponin against Colon Cancer. Journal of Biosciences and Medicines, 7, 70-86. https://doi.org/10.4236/jbm.2019.77006

Received: May 24, 2019

Accepted: July 12, 2019

Published: July 15, 2019

Copyright (c) 2019 by author(s) and Scientific Research Publishing Inc. This work is licensed under the Creative Commons Attribution International License (CC BY 4.0).

http://creativecommons.org/licenses/by/4.0/ (c) (i) Open Access

\begin{abstract}
Saponin is an important class of natural products that can be presented in many plants, it has a diverse range of properties, which include pharmacological and medicinal properties, antimicrobial, insecticidal, and anticancer activities. The aim of this study was to extract the saponin from different Egyptian legumes sources and evaluate the antitumor activity of partially purified saponin extracted from soybean in mouse colon cancer cells in vitro and compare its activity with cisplatin as reference chemotherapeutic drug. In this study saponin extracted from soybean and partially purified using silica gel column chromatography and then characterized by using IR and HPLC techniques. Antitumor activity of partially purified saponin was evaluated by using MTT assay, caspase- 9 activity and apoptotic effect by flow cytometric analysis. Our results showed that the high saponin was present in soybean with concentration $94.8 \mathrm{mg} / \mathrm{g}$ dry weight. The partially purified soybean saponin inhibited the proliferation of colon cancer cell line in a dose-dependent manner with $\mathrm{IC}_{50} 43.4 \mu \mathrm{g} / \mathrm{ml}$ after $48 \mathrm{hrs}$ treatment. The proliferation inhibitory effect of soybean saponin was associated with its apoptosis-inducing effect by activation of caspase- 9 and increasing the percent of apoptotic cells to 91.02\% when compared with negative control after analysis by flow cytometry. In conclusion, soybean saponin had antitumor activity against mouse colon cancer cell line and its mechanism was mediated through apoptotic effect.
\end{abstract}

\section{Keywords}

Saponin, Soybean, Colon Cancer, Antitumor Activity, Apoptosis

\section{Introduction}

Cancer is the second leading cause of death worldwide which characterized by out of control cell growth. Colon cancer is one of the most common cancers and 
the fourth most frequent cause of death worldwide. In addition to genetic factors that are crucial for cancer formation and development, environmental factors are important for its promotion and progression [1]. Diet is the most important exogenous factor in the etiology of colon cancer. The substantial differences in the incidence of colon cancer between the western world and developing countries can be explained by a high fiber and low fat containing diet in developing countries compared with increasing intake of fat and alcohol in western countries [2].

There are different therapies for the treatment of colon cancer but they have many bad side effects. Thus, it is important to find a new alternative for colon cancer treatment that has high efficiency and low toxicity [3]. For thousands of years, natural products have played a very important role in health care and prevention of diseases [4]. Natural products, which are a rich source of compounds with enormous structural diversity, have been extensively explored in the field of drug discovery and have led to remarkable successes particularly in the field of cancer therapeutics [5].

Saponin is an important class of natural products that can be found in many plants, as well as in some marine animals [6]. A saponin molecule consists of an aglycone (or sapogenin) and one or two sugar moieties that linked to the aglycone through an ether or ester glycosidic linkage at one or two glycosylation sites [7]. The presence of both polar (sugar) and non-polar (steroid or triterpene) groups provides saponins with strong surface-active properties which are responsible for many of its adverse and beneficial biological effects such as anticancer properties [8].

There are several in vitro studies that have evaluated the cytotoxic effect of saponins against tumor development. The antitumor effect of saponin worked through various pathways, such as anti-cancer, anti-metastatic, immunostimulation and chemoprevention [9]. Hence this study is aimed at extraction and partial purification of saponin from soybean, then the anticancer efficiency of the compound using human colon cancer cell line is investigated. To further elucidate the antitumor activity and mechanisms by which soybean saponin mediates this activity, we evaluated the effects of soybean saponin on cell proliferation and apoptosis in Coca cell line.

\section{Materials and Methods}

\subsection{Plant Sources}

Legumes: bean (Viciafaba), soybean (Glycine max), cowpeas (Vignaunguiculata), chickpea (Cicer arietinum), kidney beans (Phaseolus vulgaris) and lupine (Lupinus albus L.), which was purchased from local market, Egypt.

\subsection{Chemicals and Reagents}

Dulbecco's Modified Eagies Medium with $4.5 \mathrm{~g} / \mathrm{L}$ glucose and L-glutamine (DMEM), Trypsin EDTA, Fetal Bovine Serum and Penicillin-Streptomycin $(10.000 \mathrm{U} / \mathrm{ml}$ of penicillin and $10.000 \mu \mathrm{g} / \mathrm{ml}$ streptomycin) were purchased from Cambrex, bios- 
cience. Verviers, Belgium. (3-(4,5-dimethylthiazol-2-yl)-2,5-diphenyltetrazolium bromide) (MTT) and dimethyl sulfoxide (DMSO) were purchased from Sigma-Aldrich, USA.Caspase-9 colorimetric assay kit from Biovision, USA. Annexin V-FITC Apoptosis Detection Kit from Immunostep, Spain. Standard saponin was purchased from Fisher Scientific, UK.

\subsection{Cell Line}

Mouse colon cancer cell line (Coca) was purchased from Vacsera, Cairo, Egypt. The cells were grown in DMEM medium supplemented with $10 \%$ fetal bovine serum and penicillin/streptomycin (100 units/ml) and incubated at $37^{\circ} \mathrm{C}$ in a $5 \%$ $\mathrm{CO}_{2}$ humidified incubator.

\subsection{Extraction and Determination of Saponin from Legumes}

A modified method of [10] was used. Samples were ground and defatted with chloroform in a Soxhlet apparatus to remove the interfering pigments and lipids. $50 \mathrm{~g}$ of the defatted sample was re-extracted with $250 \mathrm{ml}$ of $95 \%$ ethanol in a Soxhlet extractor at $75^{\circ} \mathrm{C}$ for $16 \mathrm{hrs}$ till the solvent became colorless. The ethanolic extract was concentrated by evaporation of the solvent using rotary evaporator under reduced pressure. After that concentrated extract was precipitated using excess volume of acetone. The resulting precipitate was filtered and dried to give crude saponin mixture then calculated the saponin mass.

$$
\text { (Yield) } \% \mathrm{SP}=\mathrm{A} / \mathrm{SM} \text {, }
$$

While A is the mass of saponin and SM is the sample mass (per gram).

Saponin was hydrolyzed by the method of [11] and the total content of triterpenoid saponins was determined according to the method of [12] using standard saponin.

\subsection{Chromatographic Analysis}

\subsubsection{Column Chromatography}

A silica gel column (60 - 200 mesh) was used for soybean saponin purification. Concentrated crude saponin sample was applied to the column. The impurities were washed with $n$-hexane: ethanol (1:1) (two-bed volume) through a $12 \times 6$ $\mathrm{cm}$ bed of silica gel. The column was eluted with $\mathrm{n}$-butanol/ethanol/water (1:1:1). The flow rate was $4 \mathrm{ml} / 5 \mathrm{~min}$. Aliquots from fractions were applied to a strip of TLC plate and the concentration of saponin was determined in each fraction as mentioned before [13].

\subsubsection{Thin-Layer Chromatography (TLC)}

TLC analysis was carried out on aluminum plates coated with silica gel 60 (Merk KGaA Darmstadt, Germany) according to the method of [14].

\subsection{Characterization of Partially Purified Soysaponin}

\subsubsection{Fourier Transform Infrared (FTIR)}

Positive fractions from column chromatography were pooled then the solvent was evaporated and the sample was dried. The sample and standard saponin 
were ground to quite a powder with mesh sieve and mixed 1/1 with vacuum dried $\mathrm{KBr}$ powder to make compressed pellet with subsequent recording of the infrared spectrum. A JNS-CO Spectrum System 4100 LE FTIR spectrometer (Japan) was used for the analysis in the range between $4000 \mathrm{~cm}^{-1}$ and $400 \mathrm{~cm}^{-1}$ at a resolution of $4 \mathrm{~cm}^{-1}[15]$.

\subsubsection{High-Performance Liquid Chromatography (HPLC)}

Saponin from soybean was confirmed and quantified after column chromatography by using YL9100 HPLC system, Japan (C18 column) according to the method of [16].

\subsection{Cell Culture and Cytotoxicity Assay}

The human colon cancer cell line (Coca) were grown in DMEM medium supplemented with $10 \%$ fetal bovine serum and penicillin/streptomycin (100 units $/ \mathrm{ml}$ ) and incubated at $37^{\circ} \mathrm{C}$ in a $5 \% \mathrm{CO}_{2}$ humidified incubator. The effect of saponin on the viability of Coca cells was determined using the MTT assay [17]. Coca cells were seeded in 96-well plates at concentration $1 \times 10^{5}$ cells $/ \mathrm{ml}(3 \times$ $10^{4} /$ well) and incubated at $37^{\circ} \mathrm{C}$ in $5 \% \mathrm{CO}_{2}$ humidified incubator overnight then the cells were treated with different concentration of soybean saponin, standard saponin ranged from $(10-100 \mu \mathrm{g} / \mathrm{ml})$ and cisplatin as reference drug from $(1.56$ - $50 \mu \mathrm{g} / \mathrm{ml}$ ) as triplicate for each concentration. $48 \mathrm{hrs}$ later, $20 \mu \mathrm{l}$ of MTT stock solution $(5 \mathrm{mg} / \mathrm{ml})$ was added and after incubation for additional $4 \mathrm{~h}$, the absorbance at $540 \mathrm{~nm}$ was then measured on a scanning multi-well spectrophotometer. The cytotoxicity was evaluated with reference to the $\mathrm{IC}_{50}$ value.

\subsection{Caspase Activity Assay}

The activity of caspase- 9 was measured by using Colorimetric Assay Kit according to the manufacturer's protocol. Briefly, after the cancer cells were treated with soybean saponin $(0,21.7,43.4$ and $86.8 \mu \mathrm{g} / \mathrm{ml})$ and $3.8 \mu \mathrm{g} / \mathrm{ml}$ of cisplatin for $24,48 \mathrm{~h}$, cell lysates were prepared in cell lysis buffer for $10 \mathrm{~min}$ on the ice and centrifuged at $10,000 \times \mathrm{g}$ for $1 \mathrm{~min}$ at $4^{\circ} \mathrm{C}$. The supernatants were collected and total protein was quantified by Bradford method. Protein lysate was mixed with $2 \mathrm{x}$ reaction buffer and LEHD- $p \mathrm{NA}$ substrate. Developed color was measured at $405 \mathrm{~nm}$ in a microplate reader. Results are represented as the percentage of change of activity compared to the control [18].

\subsection{Apoptosis Assay}

Annexin V-FITC/PI Apoptosis Assay Kit was used to quantifying the apoptosis induced by soybean saponin treatment for 48 and $72 \mathrm{hrs}$ according to manufacturer's instructions. Briefly, after soybean saponin treatment, Coca cells were collected and washed twice in temperate PBS and resuspended in 1x Annexin binding buffer then $5 \mu \mathrm{l}$ of Annexin-V and $5 \mu \mathrm{l}$ of PI were added to $100 \mu \mathrm{l}$ of cell suspension. The samples were incubated for $15 \mathrm{~min}$ at room temperature in dark and were analyzed by flow cytometry [19]. 


\section{Results}

\subsection{Quantification of Saponin by Colorimetric Method}

Saponin was determined in 6 different Egyptian legumes species. Table 1 showed that soybean contains higher saponin with a concentration $94.89 \mathrm{mg} / \mathrm{g}$ dry weight than the other legumes while the lowest saponin concentration was present in bean $(5.7 \mathrm{mg} / \mathrm{g}$ dry weight).

\subsection{Chromatographic Analysis}

Saponin from different legumes was analyzed and confirmed using thin layer chromatography (TLC). As shown in Figure 1, there are many spots among of them a sharp blue violet spot with $\mathrm{R}_{\mathrm{f}}$ value 0.4 in each extract of legumes which confirmed the presence of saponin.

The saponin extracted from soybean was partially purified by using silica gel column chromatography (Figure 2). The saponin was found in fractions of

Table 1. Concentrations of saponin in different legumes

\begin{tabular}{cccc}
\hline Legumes & $\begin{array}{c}\text { Concentration of triterpenoid } \\
\text { saponin }(\mathrm{mg} / \mathrm{ml})\end{array}$ & $\begin{array}{c}\text { Concentration of triterpenoid } \\
\text { saponin }(\mathrm{mg} / \mathrm{g} \text { dry weight) }\end{array}$ & $\%$ Yield \\
\hline Soybean & 185.33 & 94.89 & $5.12 \%$ \\
Lupine & 45.96 & 20.77 & $4.5 \%$ \\
Cowpea & 82.71 & 13.23 & $1.6 \%$ \\
Chickpea & 57.6 & 10.59 & $1.84 \%$ \\
Kidneybean & 35.16 & 6.18 & $1.42 \%$ \\
Bean & 55.4 & 5.7 & $1.04 \%$ \\
\hline
\end{tabular}

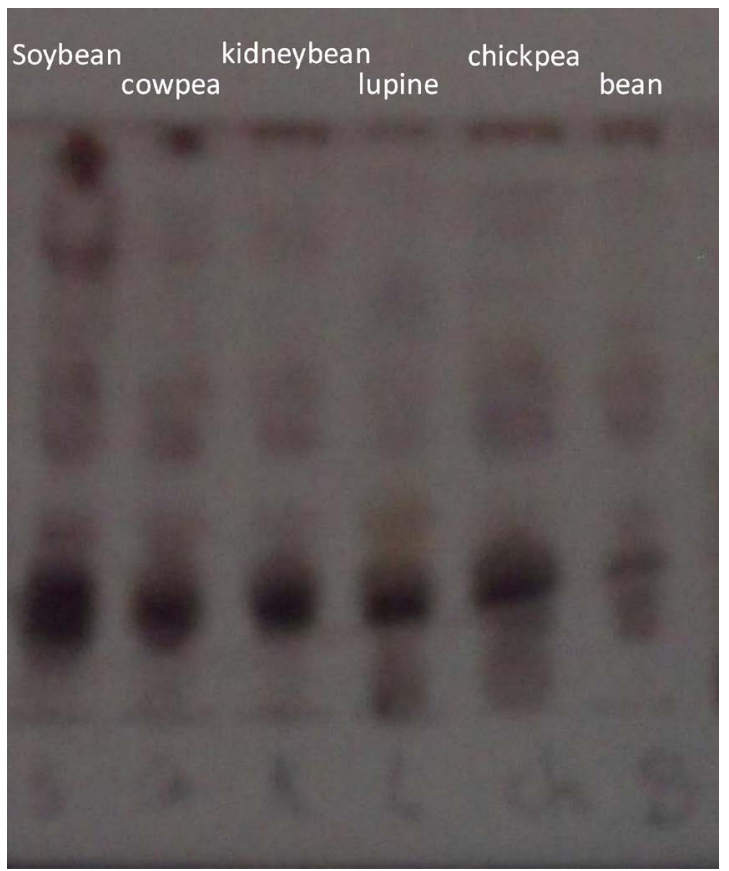

Figure 1. Thin layer chromatography. TLC of crude saponin extracted from different legumes. 
n-butanol/ethanol/water. These fractions have confirmed the presence of saponin by TLC which appeared the presence of blue-violet spots without impurities when compared to standard saponin (Figure 3). These positive fractions were pooled and the concentration of saponin after pooling was determined compared to crud saponin, the data showed that the concentration of the pooled saponin was $1671.32 \mathrm{mg}$ with yield percent $56.36 \%$ as shown in Table 2.

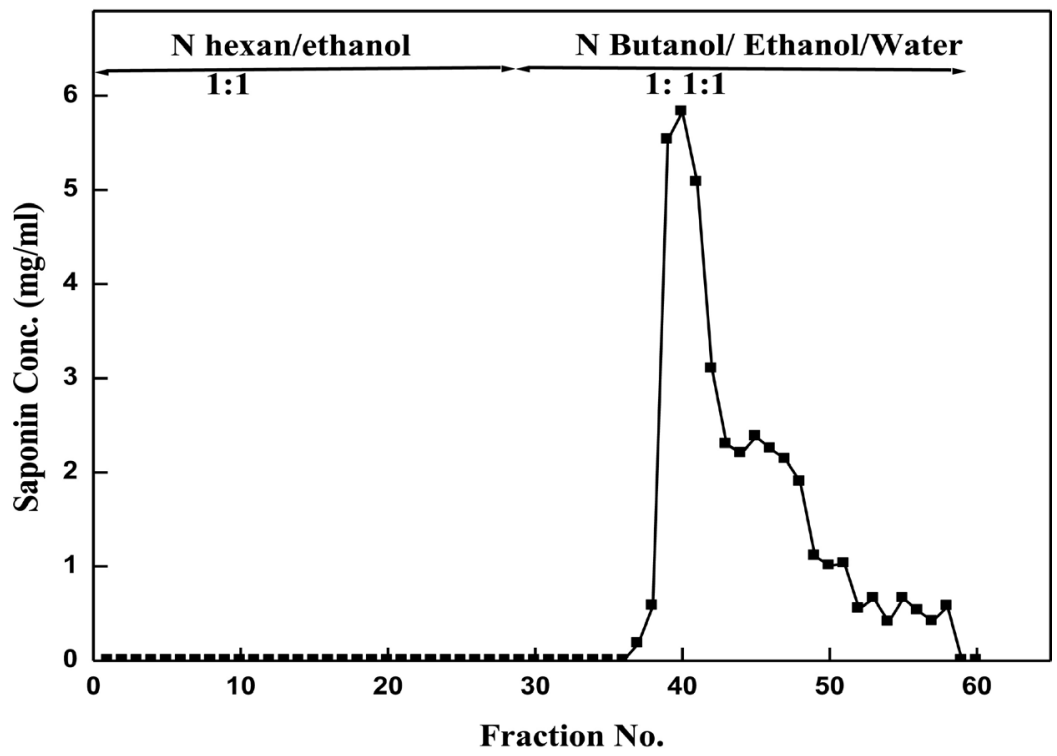

Figure 2. A typical elution profile for the chromatography of crude soybean saponin silica gel (60 - 200 mesh size $)(12 \times 2.8 \mathrm{~cm}$ i.d. $)$ at a flow rate $48 \mathrm{ml} / \mathrm{hrs}$. and $4 \mathrm{ml}$ fraction.

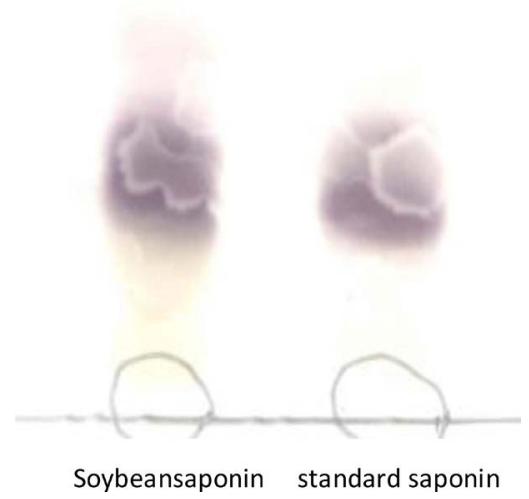

Figure 3. Thin layer chromatography. TLC of soybean saponin after column chromatography and standard saponin.

Table 2. Purification scheme of soybean saponin.

\begin{tabular}{lcccc}
\hline \multicolumn{1}{c}{ Step } & $\begin{array}{c}\text { Concentration of } \\
\text { saponin }(\mathrm{mg} / \mathrm{ml})\end{array}$ & $\begin{array}{c}\text { Volume } \\
(\mathrm{ml})\end{array}$ & $\begin{array}{c}\text { Total concentration } \\
\text { of saponin }(\mathrm{mg})\end{array}$ & \%yield \\
\hline 1. Crude extract & 185.33 & 16 & 2965.28 & $100 \%$ \\
2. Silica gel column chromatography & 34.82 & 48 & 1671.36 & $56.36 \%$ \\
\hline
\end{tabular}




\subsection{Confirmation of Saponin Existence by IR Analysis}

The Fourier transform infrared spectroscopy (FTIR) spectrum revealed the presence of C-H bond at $2927 \mathrm{~cm}^{-1}, \mathrm{C}-\mathrm{O}-\mathrm{C}$ bond at $1052 \mathrm{~cm}^{-1}, \mathrm{C}=\mathrm{C}$ bond at $1628 \mathrm{~cm}^{-1}$ and $\mathrm{OH}$ bond at $3400 \mathrm{~cm}^{-1}$ were assigned as compared with standard saponin Figure 4.

\subsection{Quantification of Saponin in Soybean by HPLC}

High-performance liquid chromatography (HPLC) analysis revealed the presence of saponin in soybean with concentration $20.5 \mathrm{mg} / \mathrm{gm}$ dry weight. Figure 5(a) and Figure 5(b) showed the chromatogram of soybean and standard saponin with retention time 1.8 and 1.7 respectively. There were other peaks with different retention times but with lower concentrations.

\subsection{Cytotoxic Effects of Soybean Saponin in Coca Cells}

After the treatment of the cells with various concentrations of standard and soybean saponin for $48 \mathrm{~h}$, the cytotoxicity was examined using the MTT assay. Our study reported that the treatment of colon cancer cells with standard and soybean saponin at a concentration $10 \mu \mathrm{g} / \mathrm{ml}$ for each for $48 \mathrm{~h}$, the viability of cells were $75.8 \%$ and $85.5 \%$ respectively. In addition, the viability of cells was decreased when standard and soybean saponin concentration was raised in a dose-dependent manner (Figure 6). The $\mathrm{IC}_{50}$ of standard and soybean saponin in Coca cells for 48 -h treatment was 28.7 and 43.4 respectively when compared with $\mathrm{IC}_{50}$ of cisplatin that was $3.8 \mu \mathrm{g} / \mathrm{ml}$ (Figure 7).

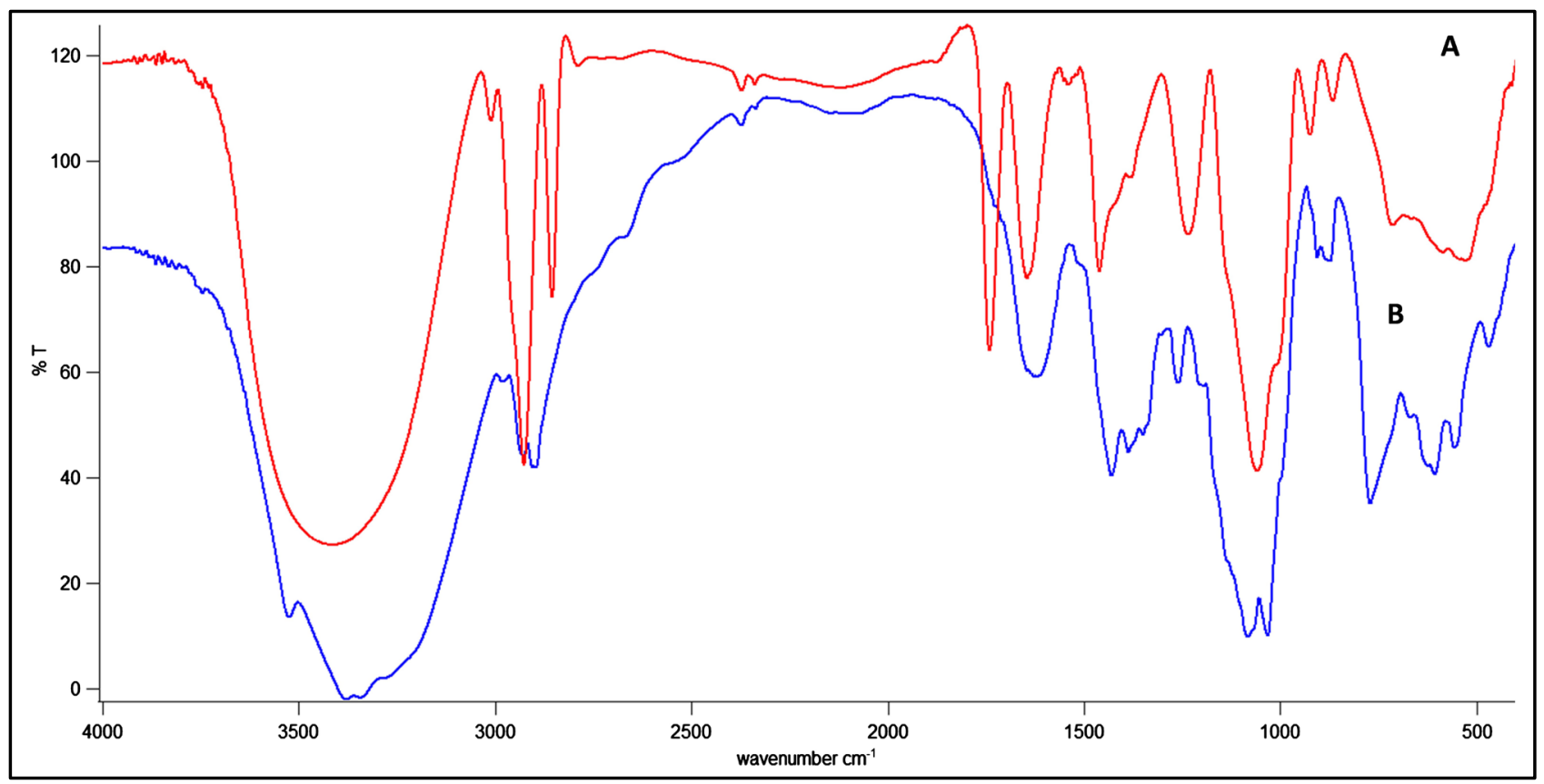

Figure 4. FTIR spectrum of standard saponin and soy saponin (A: soysaponin; B: standard saponin). 


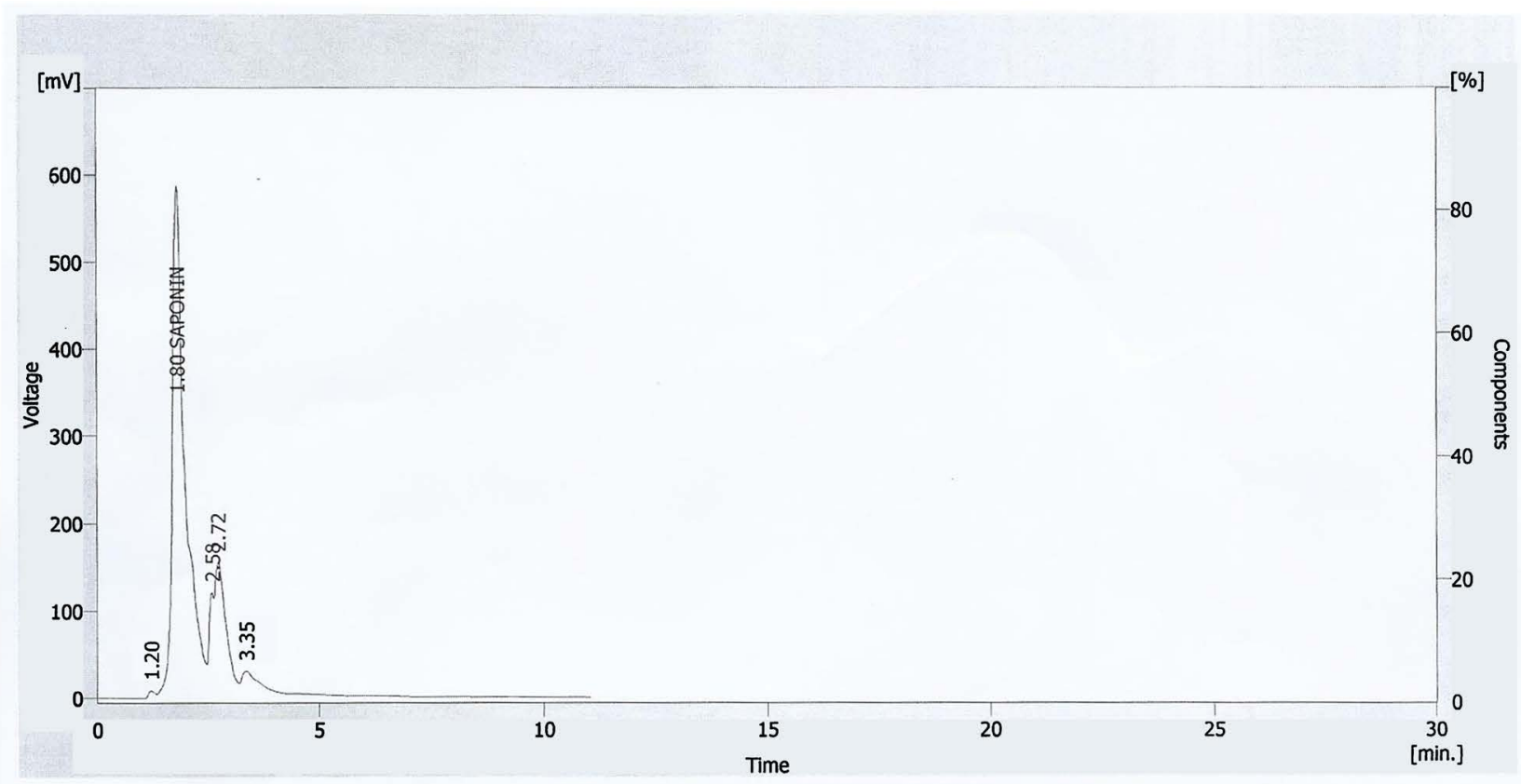

(a)

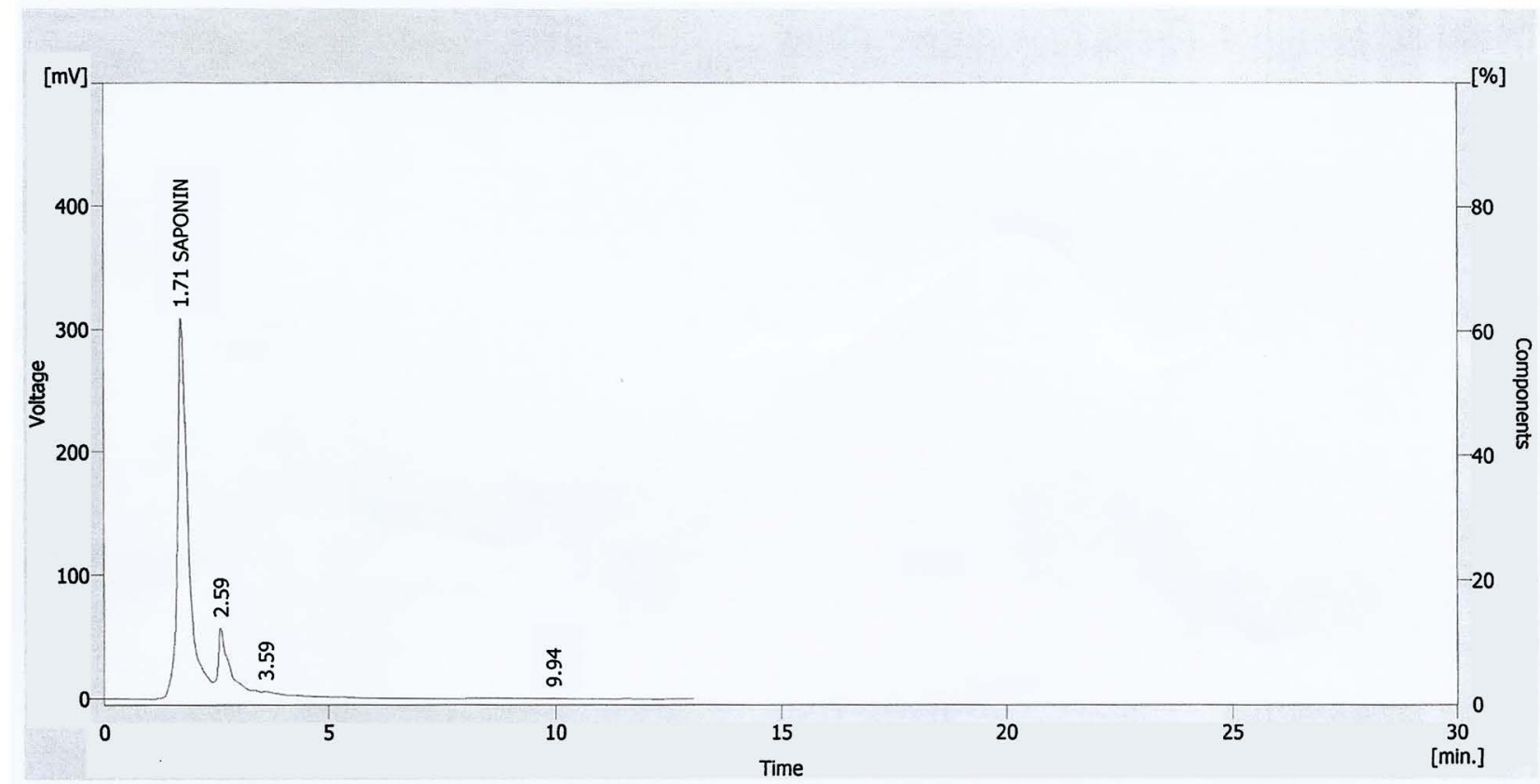

(b)

Figure 5. (a) HPLC chromatogram of saponin isolated from soybean; (b) HPLC chromatogram of standard saponin.

\subsection{Effect of Soybean Saponin on Caspase-9 Activity}

As shown in Figure 8, the activity of caspase-9 in Coca cells treated with 3.8 $\mu \mathrm{g} / \mathrm{ml}$ of cisplatin for 24 and $48 \mathrm{~h}$ was significantly increased $(p<0.01)$ to 151.8 and $217.5 \%$ of control as compared with the untreated cells but $21.7 \mu \mathrm{g} / \mathrm{ml}$ of soybean saponin had no effect on caspase- 9 activity in Coca cells treated for 24 h. In addition, the results showed that caspase- 9 activity was significantly increased in Coca cells when the concentrations of soybean saponin raised to 43.4 


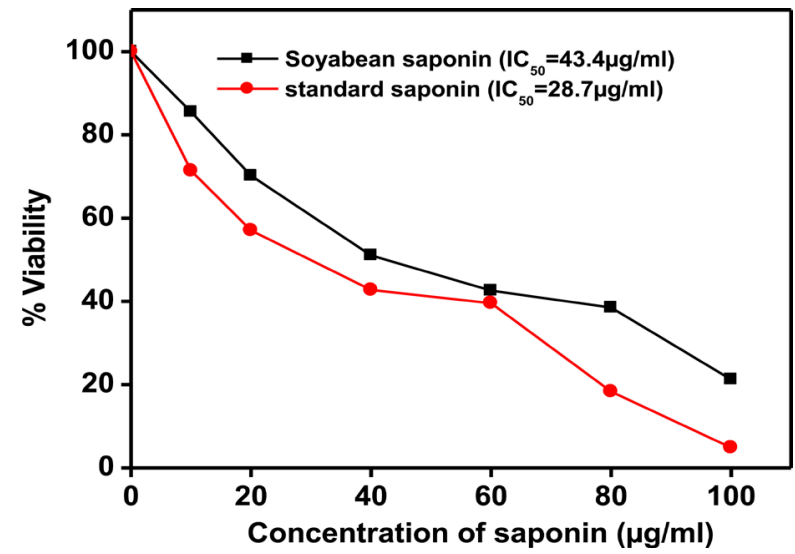

Figure 6. Effect of standard saponin and soybean saponin on Coca cell viability by the MTT assay after $48 \mathrm{~h}$ incubation. The mean percent of control ( \pm standard deviation) was calculated for each cell viability and compared with the viability of untreated cells, which was considered to corresponding $100 \%$ viability.

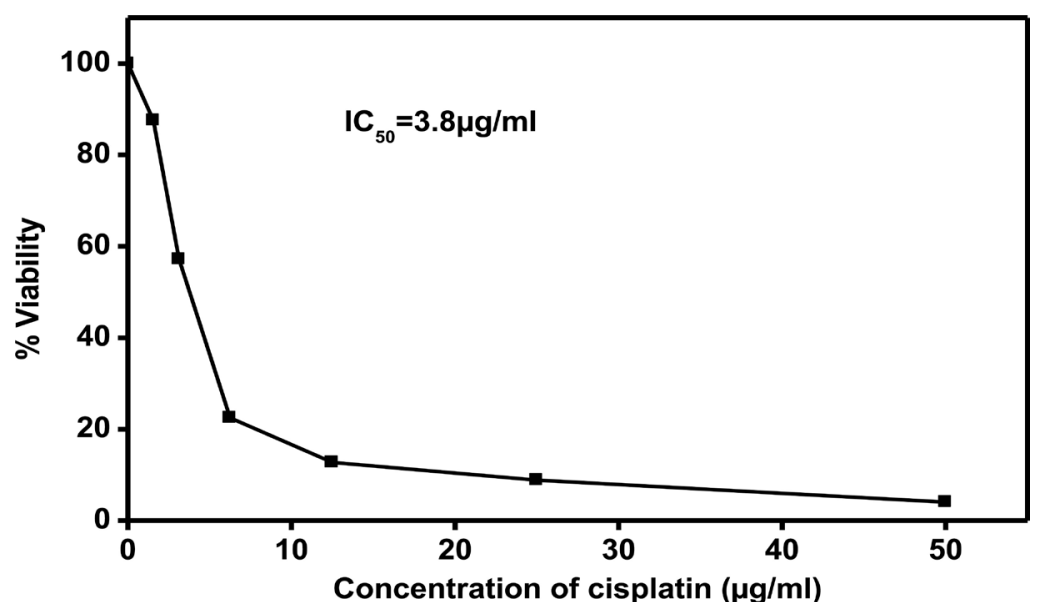

Figure 7. Effect of cisplatin on Coca cell viability by the MTT assay after $48 \mathrm{~h}$ treatment. The mean percent of control ( \pm standard deviation) was calculated for each cell viability and compared with the viability of untreated cells, which was considered to corresponding $100 \%$ viability.

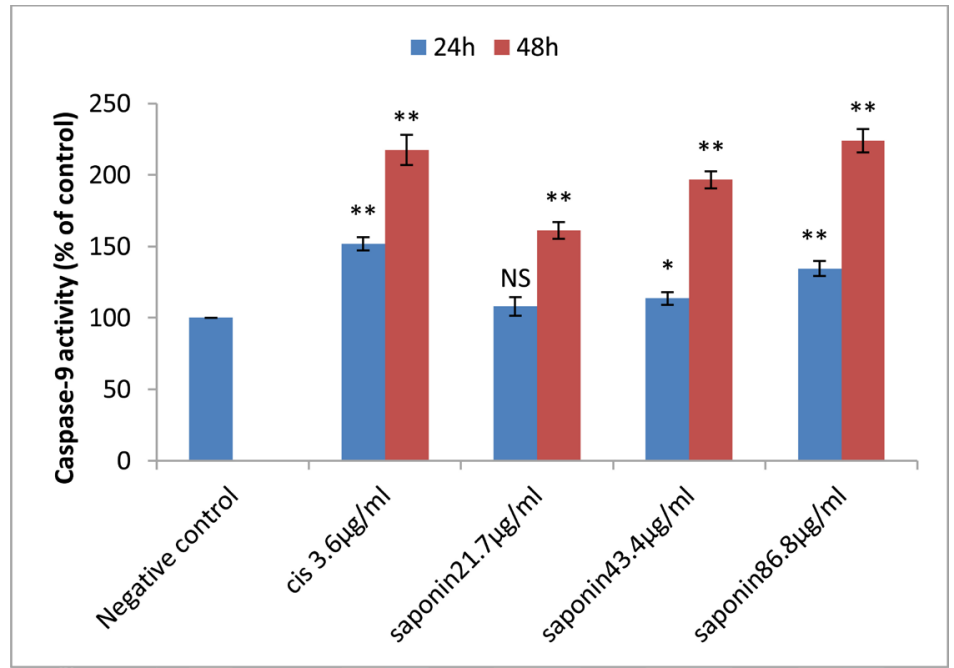

Figure 8. Effect of cisplatinand soybean saponin on caspase-9 activity in Coca cells after 24 and $48 \mathrm{~h}$ treatment. Data values are expressed as means \pm SD of triplicate determinations. 
and $86.8 \mu \mathrm{g} / \mathrm{ml}$ for 24 and $48 \mathrm{~h}$.

\subsection{Effect of Soybean Saponin on Inducing Apoptosis}

To elucidate whether the growth-inhibitory effect of soybean saponin was related to the induction of apoptosis, flow cytometric analysis with Annexin V-FITC/PI Apoptosis Assay Kit was performed. As shown in Figure 9 \& Figure 10 , soybean saponin treatment induced apoptosis in Coca cells in a dose and time-dependent manner. Compared to the untreated cells, $86.8 \mu \mathrm{g} / \mathrm{ml}$ soy saponin treatment resulted in 84.38 and $91.02 \%$ of cells being in early apoptosis after 48 and $72 \mathrm{~h}$ treatment. In addition, the incubation of Coca cells with $3.8 \mu \mathrm{g} / \mathrm{ml}$ of cisplatin for 48 and $72 \mathrm{~h}$ followed by cytometric analysis resulted in only $12.26 \%$ of cells being in early apoptosis and $32.92 \%$ of cells being in late apoptosis.

\section{Discussion}

Natural products have an important role in combating cancer. The main sources of these compounds are microbes and plants from the terrestrial and marine

(a)

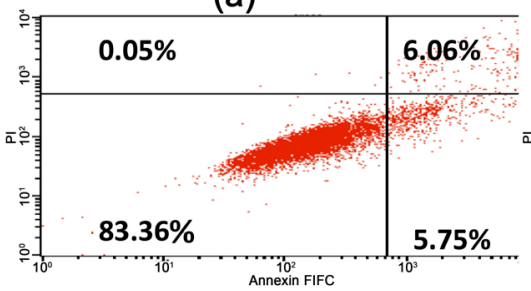

(c)

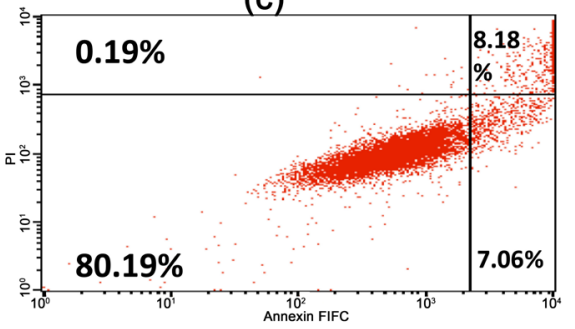

(e)

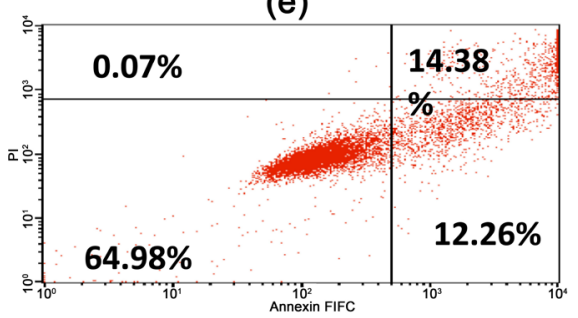

(b)

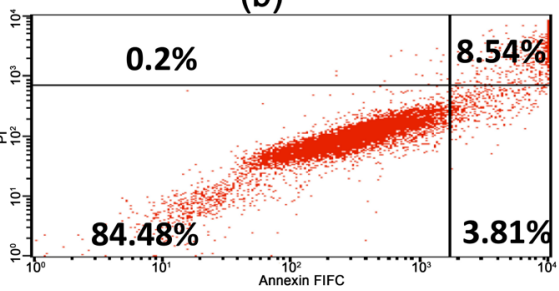

(d)

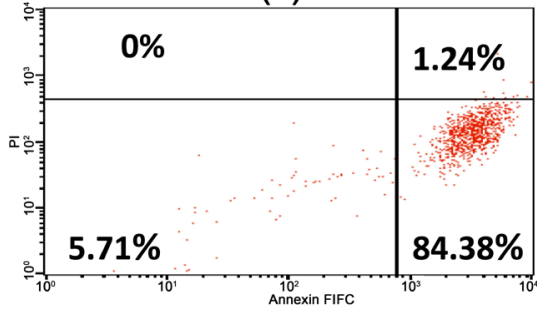

Figure 9. Flow cytometric analysis of Coca cells treated with different concentrations of soybean saponin for $48 \mathrm{~h}$. Plots show Annexin V-FITC and propidium iodide staining, panel (a)-(c) and (d) are Coca cells treated with $0,21.7,43.4$ and $86.8 \mu \mathrm{g} / \mathrm{ml}$ of soybean saponin respectively and panel (e) is Coca cell treated with $3.8 \mu \mathrm{g} / \mathrm{ml}$ cisplatin. In each panel, the lower left quadrant shows the percent of viable cells, the lower right quadrant represents the percent of apoptotic cells, the upper left quadrant represents the percent of necrotic cells and the upper right quadrant represents the percent of necrotic and apoptotic cells. 
(a)

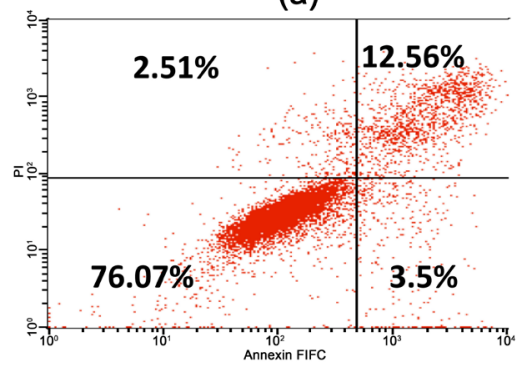

(c)

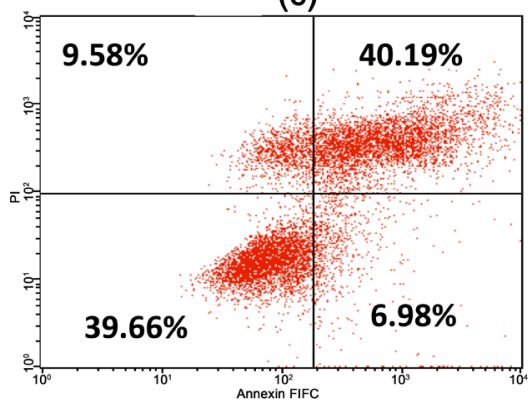

(e)

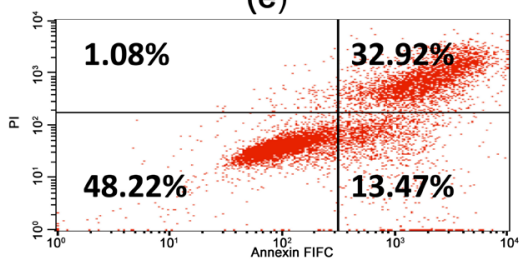

(b)

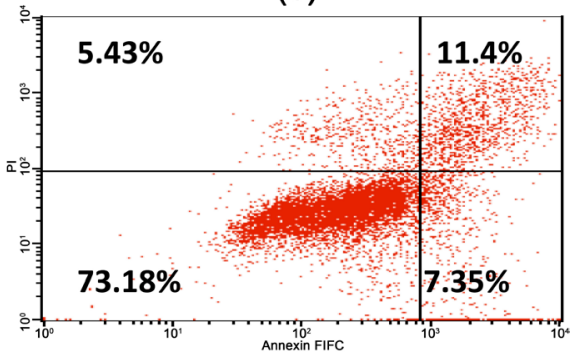

(d)

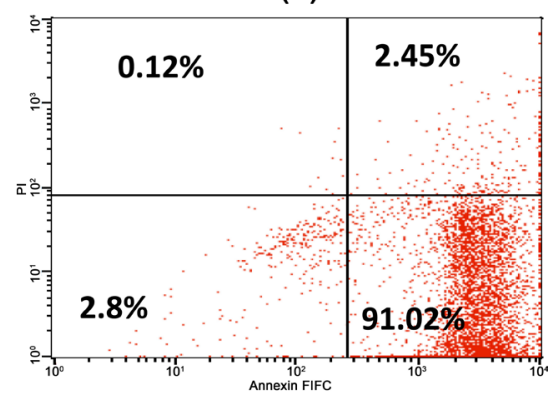

Figure 10. Flow cytometric analysis of Coca cells treated with cisplatin and different concentrations of soybean saponin for $72 \mathrm{hr}$.

environments. The search for novel drugs is still a priority goal for cancer therapy, due to the rapid development of resistance to chemotherapeutic drugs which have undesirable side-effects so the scientists trend tousing novel anti-tumor drugs active against untreatable tumors, with fewer side-effects and/or with greater therapeutic efficiency [20].

Saponins are secondary metabolites that belong to a diverse group of compounds with high chemoprevention potential which have multidirectional effects on various processes related to the promotion and progression of cancer in which they can inhibit proliferation and induce the apoptosis of tumor cells, reduce their invasive activity, also it can influence the cancer cells through the modulation of intracellular signaling pathways associated with the oxidative stress and inflammation [21] [22].

In this study, the saponin was extracted from legumes by using Soxhlet extractor. The results of this study showed that saponin present in all legumes with different concentrations but soybean is the highest source. Confirmation of saponin accomplished without expending expensive and time-consuming chemical methods as FTIR analysis and TLC. TLC was applied to confirm the presence of saponin in different legumes extracts as a simple and qualitative method. In the present study, saponin extract from lupine, cowpea, chickpea, kidney bean, 
bean and soybean before applying to the column has been separated into six fractions. Khalil and El-Adawy showed that saponin extract from peas and soybean has been separated into seven and six fractions each [13]. The obtained results showed that there are violet spots in each extract with $R_{f}$ value 0.4 when the plate was sprayed with ethanol and sulfuric acid. These results are nearly in accordance with the results reported by [23] and [24] when they extracted saponin from the leaf of Hypochae risradicata L and Sesbania sesban (L.) Merr in which TLC showed violet spots with $\mathrm{R}_{\mathrm{f}}$ values 0.56 and 0.61 respectively by using methanol and chloroform as solvent system.

In this study, the soybean saponin was separated and partially purified from soybean crude extract using silica gel column chromatography. Saponin from soybean after elution showed blue violet spots without impurities after running with TLC plate. The results showed that $\mathrm{R}_{\mathrm{f}}$ of soybean from thin layer after elution from silica gel column was 0.4 as before elution.

Fourier transform infrared spectroscopy (FTIR) technique was performed as a highly specific method for saponin identification. Recognition of saponin in soybean after partial purification by silica gel column chromatography was confirmed by infrared absorptions recorded. FTIR spectrum of the reference sample and partially purified soybean saponin indicated characteristic absorption peaks of saponin. It showed the presence of the long sharp peak at $3400 \mathrm{~cm}^{-1}$ indicates the presence of hydroxyl groups $(-\mathrm{OH})$ and the peak at $2927 \mathrm{~cm}^{-1}$ represents alkyl groups $(\mathrm{C}-\mathrm{H}) .(-\mathrm{C}=\mathrm{C})$ groups at $1628 \mathrm{~cm}^{-1}$. C-O-C bond at $1052 \mathrm{~cm}^{-1}$. The existence of $-\mathrm{OH}, \mathrm{C}-\mathrm{H}$, and $\mathrm{C}=\mathrm{C}$ bands in absorption peak of FTIR spectrum was characteristic of saponins. The C-O-C absorptions indicated glycoside linkages to the sapogenins. Therefore, FTIR spectra represented an indicative sign of presence saponin like compounds in soybean [25].

Some studies were used FTIR for saponin characterization. For instance, Amini performed FTIR spectroscopy for direct identification of saponin-like compounds isolated from Persian Gulf brittle star (Ophiocoma erinaceus) which revealed the presence of broad and strong signal of hydroxyl group (339 8.78 $\left.\mathrm{cm}^{-1}\right)$, C-H $\left(2851.54 \mathrm{~cm}^{-1}\right)$, signal olefinic $(\mathrm{C}=\mathrm{C})\left(1673.33 \mathrm{~cm}^{-1}\right)$, strong absorption signals sulfate group (C-O-C) noted at $1213.97 \mathrm{~cm}^{-1}, 1055.14 \mathrm{~cm}^{-1}$ [15].

The previous studies used FTIR technique to confirm the presence of saponin purified from Holothuria leucospilota sea cucumber which showed some peaks and absorption between 4000 and $400 \mathrm{~cm}^{-1}$. The presence of the long sharp peak at $3400.10 \mathrm{~cm}^{-1}$ indicates the presence of hydroxyl groups (-OH) and the peak at $2928.85 \mathrm{~cm}^{-1}$ represents alkyl groups $(\mathrm{C}-\mathrm{H})$. Ether $(\mathrm{C}-\mathrm{O})$ and ester $(-\mathrm{C}=\mathrm{O})$ groups are characterized by the presence of sharp peaks between 1300 and 1000 $\mathrm{cm}^{-1}$. Oligosaccharide linkage absorption to sapogenins, that is C-O-C were apparent between 1054 to $1261.08 \mathrm{~cm}^{-1}$. The identification of hydroxyl, alkyl, and ether and ester groups in the FTIR spectrum from Holothurialeucospilota sea cucumber indicate the presence of saponin [26]. 
The partially purified soybean saponin was identified by reverse phase high-performance liquid chromatography. Due to their poor chromophores, most of the soybean tri terpenoid saponins can only be detected at a wavelength of $205 \mathrm{~nm}$ which indicated that the peaks obtained before 5 minutes were saponins as compared with the standard. In HPLC chromatogram of standard and soybean saponin, there were high peaks obtained at retention time 1.7 and 1.8 respectively with concentration $20.6 \mathrm{mg} / \mathrm{g}$ dry weight. These results are in agreement with the previous study reported by Rupasinghe et al. in which the concentration of saponin in soya bean was $15.6 \mathrm{mg} / \mathrm{g}$ dry weight in three different cultivars of soya bean by using reverse-phase high-performance liquid chromatography (RP-HPLC) with external standards [27].

In this study, the antitumor activity of cisplatin as reference chemotherapeutic drug, standard saponin and soybean saponin on colon cancer cells in vitro was evaluated by using MTT cytotoxicity assay. The results of the present study demonstrated that standard saponin and soybean saponin are cytotoxic to human colon cancer cells in which they decreased the viability of Coca cells in a dose-dependent manner after $48 \mathrm{hr}$ treatment with $\mathrm{IC}_{50}$ value 28.7 and 43.4 $\mu \mathrm{g} / \mathrm{ml}$ respectively. In addition, the data showed that cisplatin has potent cytotoxic activity against human colon cancer cells with an $\mathrm{IC}_{50}$ value of $3.8 \mu \mathrm{g} / \mathrm{ml}$. Other study showed that crude saponin isolated from Platycodi Radix induces apoptosis in HT-29 colon cancer cell line with $\mathrm{IC}_{50}$ value $37.07 \mu \mathrm{g} / \mathrm{ml}$ in $24 \mathrm{~h}$ treatment [28].

Also in this regard, saponins isolated from Solanum trilobatum leaf is preferentially cytotoxic to human larynx carcinoma cells in a dose-dependent manner with an $\mathrm{IC}_{50}$ value of $1 \mathrm{mg} / \mathrm{ml}$ after $24 \mathrm{hr}$ treatment [29]. Moreover, Lu et al. study showed that the viability of human breast cancer cells (MCF-7) was decreased when Rhizoma Paridis saponins concentration was raised in adose-dependent manner with an $\mathrm{IC}_{50}$ value of $71.2 \mu \mathrm{g} / \mathrm{ml}$ after $48 \mathrm{hr}$ treatment [30].

Treatment of tumors is directed not only on inhibition of cell proliferation but also on induction of apoptosis of tumor cells. The caspase family plays an important role in the regulation of apoptosis. Caspase activation is a hallmark of apoptosis induction in response to death-inducing signals originating from cell-surface receptors, mitochondria or the endoplasmic reticulum [31]. Caspase-9 is an important member of the caspase family; cleaved caspase- 9 further processes other caspase members, including caspase- 3 and caspase-7, to initiate a caspase cascade, which leads to apoptosis [32].

In this study, to elucidate the a poptotic mechanism that is induced by soybean saponinin Coca cells, we measured the activity of caspase- 9 enzyme. The results showed that soybean saponin significantly increased the activity of caspase-9 enzyme when the cells were treated with different concentrations of soybean saponin for $48 \mathrm{hr}$ as compared with the untreated cells but in the first day of treatment only soybean saponin at a concentration $86.8 \mu \mathrm{g} / \mathrm{ml}$ and 3.8 $\mu \mathrm{g} / \mathrm{ml}$ of cisplatin can affect the activity of caspase- 9 enzyme but the lower con- 
centrations had no effect. These results are in line with the study of Kim et al. when they evaluated the effect of crude saponin from Platycodi Radix on induction of apoptosis in colon cancer cells by measuring the activity of caspase- 9 enzyme. They found that 60 and $80 \mu \mathrm{g} / \mathrm{ml}$ of this saponin significantly increased caspase- 9 activity after $24 \mathrm{hr}$ treatment. Other study showed that 20(S)-Protopanaxadiol induce human breast cancer cell apoptosis through the activation of caspase-9 enzyme when the cells were treated with 15, 30 and 60 $\mu \mathrm{M}$ of 20(S)-PPD for $24 \mathrm{hr}$ [33].

Apoptosis is a normal genetically programmed process that occurs during embryonic development, as well as in the maintenance of tissue homeostasis, under pathological conditions, and in aging [34]. The process is characterized by specific morphologic features, including loss of plasma membrane asymmetry and attachment, plasma membrane blebbing, condensation of the cytoplasm and nucleus, and inter nucleosomal cleavage of DNA. Loss of plasma membrane asymmetry is one of the earliest features of apoptosis. Therefore, staining with Annexin $\mathrm{V}$ is typically used in conjunction with a vitaldye such as a propidium iodide (PI) for identification of early and late apoptotic cells. Viable cells with intact membranes exclude PI, whereas the membranes of dead and damaged cells are permeable to PI [35].

The results that obtained from this study showed that the incubation of Coca cells with $3.8 \mu \mathrm{g} / \mathrm{ml}$ of cisplatin for $48 \mathrm{hr}$ resulted in only $12.26 \%$ of cells being in early apoptosis while the incubation of cells with 21.7 and $43.4 \mu \mathrm{g} / \mathrm{ml}$ of soybean saponin for the same period had not any apoptotic effect compared with the untreated cells. In addition, more increase in the percent of apoptotic cells was observed when the cells were incubated with $86.8 \mu \mathrm{g} / \mathrm{ml}$ of soybean saponin for 72 h (91.08\%). However, the percentage of both Annexin V-FITC and PI positive cells after the cells were treated with $3.8 \mu \mathrm{g} / \mathrm{ml}$ of cisplatin and $43.4 \mu \mathrm{g} / \mathrm{ml}$ of soybean saponin for $72 \mathrm{hr}$ increased from 11.40 to 32.92 and from 11.40 to 40.19 respectively, indicated that cells were either in the end stage of apoptosis or undergoing necrosis.

There are several reports studied the effect of different saponins from different plants on the proliferation of different types of cancer cells in vitro through the induction of apoptosis. For instance, Rhizoma Paridis saponins induced the apoptosis in human breast cancer cell line (MCF-7) when treated with different concentrations of RPS for $48 \mathrm{hr}$ treatment, the results showed that the percentage of apoptotic cells increased from $1.3 \%$ to $33.5 \%$ in adose-dependent manner, indicated that the cells were in the early stage of apoptosis [30]. Furthermore, Cheng et al. studied the apoptotic effect of D Rhamnose b-Hederin, a Novel Oleanane-Type Triterpenoid Saponin on human breast cancer cells, who found that DRB-H induced the apoptosis in MCF-7 by increasing the percentage of apoptotic cells from $2.7 \%$ to $90.5 \%$ when treated with $40 \mu \mathrm{g} / \mathrm{ml}$ of DRB-H for $48 \mathrm{hr}$ [36]. From the reports above and from the results of this study, we expected that saponins affected on the proliferation of different cancer cells by the induction of apoptosis which depends on the cell type and the type of saponin 
used in the study.

\section{Conclusion}

This study demonstrated that soybean saponin has a potent inhibitory effect on the proliferation of Coca mouse colon cancer cells in vitro. The induction of apoptosis by soybean saponin was confirmed via the activation of caspase- 9 enzyme and loss of plasma membrane asymmetry which leads to increasing the percentage of apoptotic cells by Annexin- $\mathrm{V}$ flow cytometric analysis. These results suggest that soy saponin may be potentially used as an anticancer agent against human colon cancer.

\section{Acknowledgements}

This research was supported by the authors of this study who thanks, all members in Faculty of Science, Tanta University, Egypt.

\section{Conflicts of Interest}

The authors declare no conflicts of interest regarding the publication of this paper.

\section{References}

[1] Ruiz, R.B. and Hernández, P.S. (2014) Diet and Cancer: Risk Factors and Epidemiological Evidence. Maturitas, 77, 202-208. https://doi.org/10.1016/j.maturitas.2013.11.010

[2] Tuan, J. and Chen, Y.-X. (2016) Dietary and Lifestyle Factors Associated with Colorectal Cancer Risk and Interactions with Microbiota: Fiber, Red or Processed Meat and Alcoholic Drinks. Gastrointestinal Tumors, 3, 17-24. https://doi.org/10.1159/000442831

[3] Ottaiano, A., Franco, R., Talamanca, A.A., Liguori, G., et al. (2006) Overexpression of Both CXC Chemokine Receptor 4 and Vascular Endothelial Growth Factor Proteins Predicts Early Distant Relapse in Stage II-III Colorectal Cancer Patients. Clinical Cancer Research, 12, 2795-2803. https://doi.org/10.1158/1078-0432.CCR-05-2142

[4] Phillipson, J.D. (2001) Phytochemistry and Medicinal Plants. Phytochemistry, 56, 237-243. https://doi.org/10.1016/S0031-9422(00)00456-8

[5] Newman, D.J., Cragg, G.M. and Snader, K.M. (2003) Natural Products as Sources of New Drugs over the Period 1981-2002. Journal of Natural Products, 66, 1022-1037. https://doi.org/10.1021/np0300961

[6] Moses, T., Papadopoulou, K.K. and Osbourn, A. (2014) Metabolic and Functional Diversity of Saponins, Biosynthetic Intermediates and Semi-Synthetic Derivatives. Critical Reviews in Biochemistry and Molecular Biology, 49, 439-462. https://doi.org/10.3109/10409238.2014.953628

[7] Güçlü-Üstündağ, Ö. and Mazza, G. (2007) Saponins: Properties, Applications and Processing. Critical Reviews in Food Science and Nutrition, 47, 231-258. https://doi.org/10.1080/10408390600698197

[8] Zhao, H., Harding, S.V., Marinangeli, C.P.F., Kim, Y.S. and Jones, P.J.H. (2008) Hypocholesterolemic and Anti-Obesity Effects of Saponins from Platycodon gran- 
diflorum in Hamsters Fed Atherogenic Diets. Journal of Food Science, 73, H195-H200. https://doi.org/10.1111/j.1750-3841.2008.00915.x

[9] Bachran, C., Bachran, S., Sutherland, M., Bachran, D. and Fuchs, H. (2008) Saponins in Tumor Therapy. Mini Reviews in Medicinal Chemistry, 8, 575-584. https://doi.org/10.2174/138955708784534445

[10] Tani, T., Katsuki, T., Kubo, M., Arichi, S. and Kitagawa, I. (1985) Histochemistry. V. Soyasaponins in Soybeans (Glycine max MERRILL, Seeds). Chemical and Pharmaceutical Bulletin, 33, 3829-3833. https://doi.org/10.1248/cpb.33.3829

[11] Uematsu, Y., Hirata, K., Saito, K. and Kudo, I. (2000) Spectrophotometric Determination of Saponin in Yucca Extract Used as Food Additive. Journal of AOAC International, 83, 1451-1454.

[12] Xiang, Z., Tang, C., Chen, G. and Shi, Y. (2000) Studied on Corlorimetric Determination of Oleanolic Acid in Chinese Quince. Natural Product Research and Development, 13, 23-26.

[13] Khalil, A. and El-Adawy, T. (1994) Isolation, Identification and Toxicity of Saponin from Different Legumes. Food Chemistry, 50, 197-201. https://doi.org/10.1016/0308-8146(94)90120-1

[14] Kerem, Z., German-Shashoua, H. and Yarden, O. (2005) Microwave-Assisted Extraction of Bioactive Saponins from Chickpea (Cicer arietinum L). Journal of the Science of Food and Agriculture, 85, 406-412. https://doi.org/10.1002/jsfa.1989

[15] Amini, E., Nabiuni, M., Baharara, J., Parivar, K. and Asili, J. (2014) Hemolytic and Cytotoxic Effects of Saponin Like Compounds Isolated from Persian Gulf Brittle Star (Ophiocoma erinaceus). Journal of Coastal Life Medicine, 2, 762-768.

[16] Snyder, L.R., Kirkland, J.J. and Glajch, J.L. (2012) Practical HPLC Method Development. John Wiley \& Sons, Hoboken, NJ.

[17] Denizot, F. and Lang, R. (1986) Rapid Colorimetric Assay for Cell Growth and Survival: Modifications to the Tetrazolium Dye Procedure Giving Improved Sensitivity and Reliability. Journal of Immunological Methods, 89, 271-277. https://doi.org/10.1016/0022-1759(86)90368-6

[18] Kuo, P.-L., Hsu, Y.-L., Chang, C.-H. and Lin, C.-C. (2005) The Mechanism of Ellipticine-Induced Apoptosis and Cell Cycle Arrest in Human Breast MCF-7 Cancer Cells. Cancer Letters, 223, 293-301. https://doi.org/10.1016/j.canlet.2004.09.046

[19] Herrero-Martin, D., Osuna, D., Ordóñez, J.L., Sevillano, V., et al. (2009) Stable Interference of EWS-FLI1 in an Ewing Sarcoma Cell Line Impairs IGF-1/IGF-1R Signalling and Reveals TOPK as a New Target. British Journal of Cancer, 101, 80-90. https://doi.org/10.1038/sj.bjc.6605104

[20] Demain, A.L. and Vaishnav, P. (2011) Natural Products for Cancer Chemotherapy. Microbial Biotechnology, 4, 687-699. https://doi.org/10.1111/j.1751-7915.2010.00221.x

[21] Bishayee, A., Ahmed, S., Brankov, N. and Perloff, M. (2011) Triterpenoids as Potential Agents for the Chemoprevention and Therapy of Breast Cancer. Frontiers in Bioscience: A Journal and Virtual Library, 16, 980-996. https://doi.org/10.2741/3730

[22] Bommareddy, A., Eggleston, W., Prelewicz, S., Antal, A., Witczak, Z., McCune, D.F. and Vanwert, A.L. (2013) Chemoprevention of Prostate Cancer by Major Dietary Phytochemicals. Anticancer Research, 33, 4163-4174.

[23] Dande, P.R. (2016) Evaluation of Crude Saponins Extract from Leaves of Sesbania sesban (L.) Merr. for Topical Anti-Inflammatory Activity. International Journal of Research in Pharmaceutical Sciences, 1, 296-299. 
[24] Senguttuvan, J. and Paulsamy, S. (2014) Thin Layer Chromatographic Analysis for Various Secondary Metabolites in the Methanolic Root and Leaf Extracts of Hypochaeris radicata L. American Journal of Pharmtech Research, 4, 145-156.

[25] Kareru, P., Keriko, J.M., Gachanja, A.N. and Kenji, G.M. (2008) Direct Detection of Triterpenoid Saponins in Medicinal Plants. African Journal of Traditional, Complementary and Alternative Medicines, 5, 56-60. https://doi.org/10.4314/ajtcam.v5i1.31257

[26] Soltani, M., Parivar, K., Baharara, J., Kerachian, M.A. and Asili, J. (2014) Hemolytic and Cytotoxic Properties of Saponin Purified from Holothuria leucospilota Sea Cucumber. Reports of Biochemistry \& Molecular Biology, 3, 43-50.

[27] Rupasinghe, H.V., Jackson, C.-J.C., Poysa, V., Berardo, C.D., et al. (2003) Soyasapogenol A and B Distribution in Soybean (Glycine max L. Merr.) in Relation to Seed Physiology, Genetic Variability, and Growing Location. Journal of Agricultural and Food Chemistry, 51, 5888-5894. https://doi.org/10.1021/jf0343736

[28] Kim, M.O., Moon, D-O., Choi, Y.H., Lee, J.-D., et al. (2008) Platycodin D Induces Mitotic Arrest in Vitro, Leading to Endoreduplication, Inhibition of Proliferation and Apoptosis in Leukemia Cells. International Journal of Cancer, 122, 2674-2681. https://doi.org/10.1002/ijc.23442

[29] Kanchana, A. and Balakrishna, M. (2011) Anti-Cancer Effect of Saponins Isolated from Solanum trilobatum Leaf Extract and Induction of Apoptosis in Human Larynx Cancer Cell Lines. International Journal of Pharmacy and Pharmaceutical Sciences, 3, 356-364.

[30] Lu, C., Li, C.J., Wu, D., Lu, J.M., Wang, L. and Tu, F. (2011) Induction of Apoptosis by Rhizoma Paridis Saponins in MCF-7 Human Breast Cancer Cells. African Journal of Pharmacy and Pharmacology, 5, 1086-1091.

[31] Yang, L., Wu, S., Zhang, Q., Liu, F. and Wu, P. (2007) 23, 24-Dihydrocucurbitacin B Induces $\mathrm{G}_{2} / \mathrm{M}$ Cell-Cycle Arrest and Mitochondria-Dependent Apoptosis in $\mathrm{Hu}$ man Breast Cancer Cells (Bcap37). Cancer Letters, 256, 267-278. https://doi.org/10.1016/j.canlet.2007.06.018

[32] Deveraux, Q.L., Roy, N., Stennicke, H.R., Van Arsdale, T., et al. (1998) IAPs Block Apoptotic Events Induced by Caspase- 8 and Cytochrome $c$ by Direct Inhibition of Distinct Caspases. The EMBO Journal, 17, 2215-2223.

https://doi.org/10.1093/emboj/17.8.2215

[33] Zhang, H., Xu, H.L., Fu, W.W., Xin, Y., Li, M.W., Wang, S.J., Yu, X.F. and Sui, D.Y. (2014) 20(S)-Protopanaxadiol Induces Human Breast Cancer MCF-7 Apoptosis through a Caspase-Mediated Pathway. Asian Pacific Journal of Cancer Prevention, 15, 7919-7923. https://doi.org/10.7314/APJCP.2014.15.18.7919

[34] Kerr, J.F., Wyllie, A.H. and Currie, A.R. (1972) Apoptosis: A Basic Biological Phenomenon with Wide-Ranging Implications in Tissue Kinetics. British Journal of Cancer, 26, 239-257. https://doi.org/10.1038/bjc.1972.33

[35] van Engeland, M., Ramaekers, F.C.S., Schutte, B. and Reutelingsperger, C.P.M. (1996) A Novel Assay to Measure Loss of Plasma Membrane Asymmetry during Apoptosis of Adherent Cells in Culture. Cytometry, 24, 131-139.

https://doi.org/10.1002/(SICI)1097-0320(19960601)24:2<131::AID-CYTO5>3.0.CO; $\underline{2-\mathrm{M}}$

[36] Cheng, L., Xia, T.-S., Wang, Y.-F., Zhou, W.B., et al. (2014) The Apoptotic Effect of D Rhamnose $\beta$-Hederin, a Novel Oleanane-Type Triterpenoid Saponin on Breast Cancer Cells. PLoS ONE, 9, e90848. https://doi.org/10.1371/journal.pone.0090848 